\title{
Synthesis and Mesomorphic Properties of Novel Bent-shaped Naphthyl Diketones
}

\author{
Anđela Buljan, Anamarija Knežević, Irena Dokli, Andreja Lesac*
}

\author{
Ruđer Bošković Institute, Bijenička cesta 54, HR-10000 Zagreb, Croatia \\ * Corresponding author's e-mail address: Andreja.Lesac@irb.hr
}

RECEIVED: July 1, 2019 * REVISED: July 12, 2019 * ACCEPTED: July 14, 2019

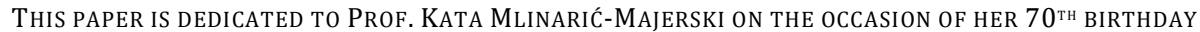

Abstract: The synthesis and liquid-crystalline properties are reported for novel naphthyl-based diketones incorporating variant terminal chains and lateral fluoro- substitution. Newly prepared materials exhibit a broad temperature range of the nematic phase. The study demonstrates how subtle structural modifications can be exploited to alter the efficiency of molecular packing and consequently the thermal behaviour.

Keywords: liquid crystals, bent-shaped dimers, naphthyl diketones.

\section{INTRODUCTION}

$\mathbf{T}$ HE liquid-crystalline state of matter, which exists between the crystalline solid and amorphous liquid states, share the anisotropic (direction dependent) properties of crystalline state and fluid properties of isotropic liquids. Molecular shape, "microphase segregation" and specific molecular interactions are important factors that drive the formation of various LC phases in the matter. ${ }^{[1,2]}$ Though liquid crystals are primarily known for their technological applications in the liquid-crystal displays (LCDs) their domain spans across multiple disciplines of pure and applied science including bioscience and materials science. ${ }^{[3]}$

For many years liquid crystalline dimers, in which two mesogenic units are linked by a flexible spacer, have been studied due to their ability to serve as model compounds for liquid-crystalline polymers and their rich and unusual mesomorphism, which differs from that of the corresponding monomers ${ }^{[4]}$ One of the main characteristics of this class of materials is that their mesomorphic properties depend on the parity of the flexible spacer and the nature of the link between the spacer and the mesomorphic units. Thus, in dimers with an evennumbered spacer, the mesogenic groups are disposed to give an overall rod-like shape, whereas, with an odd- numbered spacer, the mesogenic groups are inclined with respect to each other giving a bent-shaped motif. The recent discovery of a twist-bend nematic phase $\left(\mathrm{N}_{\mathrm{TB}}\right)$ found in odd-membered dimers has sparked a great interest in this class of materials. ${ }^{[5,6]}$ The reason for such interest is not only its promising technological applications, but also the fact that the $\mathrm{N}_{\text {тв }}$ phase is one of the most recent examples of spontaneous chirality. Unlike the uniaxial nematic phase in which a preferred direction of molecules is parallel to the main molecular axis (Figure 1a), the $\mathrm{N}_{\text {Tв }}$ phase is characterized by a spontaneous twist-bend distortion of the nematic director, which is organized on a conical helix (Figure 1b). Formation of degenerate helices does not require molecular chirality, instead, it is facilitated by the shape of bent molecules. ${ }^{[7-10]}$ Initially proposed as a theoretical possibility, ${ }^{[11]}$ the $\mathrm{N}_{\text {ТВ }}$ phase has been identified $[6,7,12]$ and intensively studied aiming to understand its structural characteristics and macroscopic properties. ${ }^{[7-9,13-17]}$ Although predominantly exhibited by liquid crystal dimers having odd-number of methylene units in the spacer, the $\mathrm{N}_{\text {Тв }}$ phase has also been reported for trimers and tetramers ${ }^{[18-22]}$ including a semi-flexible bentcore liquid crystal. ${ }^{[10,23]}$

The structure-property relation essential for the emergence of the $\mathrm{N}_{\text {тв }}$ phase has been intensively studied. To date, the work involved modifications of the mesogenic 
(a)

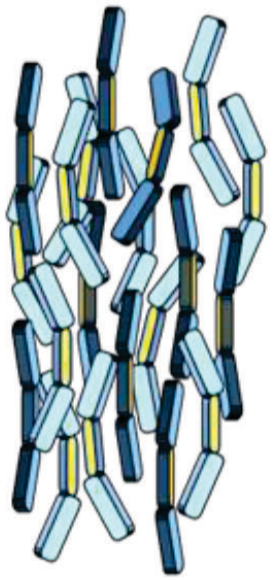

(b)

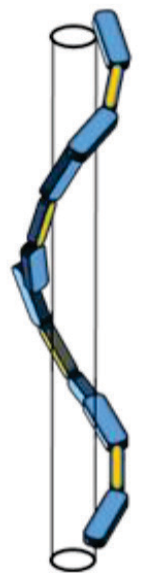

Figure 1. Cartoon illustration of the molecular organization in (a) uniaxial nematic phase, (b) $\mathrm{N}_{\mathrm{TB}}$ phase.

units and the terminal groups attached to them, ${ }^{[24-27]}$ variation of linkage groups and the length of the spacer. ${ }^{[28,29]}$ It has been reported that the stability of the $\mathrm{N}_{\text {Tв }}$ phase is affected by molecular bending defined as the angle between the two mesogenic arms, ${ }^{[24,30,31]}$ conformational distribution, ${ }^{[32,33]}$ the bend angle fluctuation, ${ }^{[14]}$ intramolecular torsion, ${ }^{[28,29]} \pi-\pi$ interactions ${ }^{[34]}$ and the effect of free volume. ${ }^{25,35]}$ The recent study of the electroclinic effect in the $\mathrm{N}_{\text {TB }}$ phase ( $E C E_{\mathrm{NTB}}$ ) discussed the improvements of the physical properties of $\mathrm{N}_{\mathrm{TB}}$ materials that might lead to possible technological applications of the fast $\mathrm{N}_{\text {TB }}$ electro-optic effects. ${ }^{[36]}$ Despite the growing number of compounds exhibiting the $\mathrm{N}_{\text {Тв }}$ phase, diverse libraries of materials are required to optimize mesomorphic and other physical properties necessary for a potential application.

Previously we have shown that naphthyl-based diketones with ethoxy and butyloxy terminal chains exhibit the nematic and the monotropic $\mathrm{N}_{\text {Тв }}$ phase. Tuning the mesomorphic properties of naphthyl-based diketones, we explore the effect of propargyl terminal chain and position of lateral fluoro substituent inserted in the outer-ring of the mesogenic core. Propargyl group is attractive substituent due to its ability to undergo polymerization while lateral fluorination may offer improved electro-optical properties as demonstrated for a vast number of fluorinated calamitic liquid crystals. ${ }^{[37]}$

\section{RESULTS AND DISCUSSION}

The target materials were prepared according to the synthetic route described in Scheme 1. The main precursor 4 was successfully prepared following the procedures reported earlier. ${ }^{[34]}$ 4-O-substituted benzoic acid $\mathbf{5 a - d}$ were prepared from corresponding hydroxybenzoic acids by Williams reaction. Esterification of $\mathbf{4}$ with appropriate benzoyl chlorides using 4-dimethylaminopyridine (DMAP) and triethylamine $\left(\mathrm{Et}_{3} \mathrm{~N}\right)$ provided target molecules in 69$77 \%$ yield.

The mesomorphic behaviour of new compounds was investigated by polarising optical microscopy and differential scanning calorimetry. The phase transition temperatures and the corresponding enthalpy changes are collected in Table 1. The DSC traces of the heating and cooling cycles are given in Supplementary Information.

The data listed in Table 1 shows that all dimers exhibit a wide temperature range enantiotropic nematic phase. The nematic phase was identified according to characteristic schlieren texture containing both two and four brush point singularities observed through the polarising microscope, and which flashed when subjected to mechanical stress (Figure 2).

Comparison of transition temperatures between newly prepared compounds and BNC-72 revealed that structural modifications result in a general reduction of the clearing point while the melting temperatures are variable, with no $\mathrm{N}$ to $\mathrm{N}_{\text {TB }}$ transition being detected. Due to the supercooling effect, all materials show a very large temperature range of the nematic phase. The effects of structural modifications on the thermodynamic behaviour of parent ethoxy analogue BNC-72 ${ }^{[34]}$ is illustrated in Figure 3. Since both, ethyloxy and butyloxy homologues display the monotropic $\mathrm{N}_{\text {Тв }}$ phase, ${ }^{[34]}$ the absence of the $\mathrm{N}_{\text {тв }}$ phase in propoxy and propargyloxy homologues is rather surprising. Also, these results are in contradiction to those observed for methylene-linked dimers which have shown that terminal chains of odd parity give more stable $\mathrm{N}_{T B}$ phases than those of even parity. ${ }^{[28]}$ It appears that the initial elongation of the chain disrupts the molecular packing required for the $\mathrm{N}_{\text {TB }}$ phase formation, while subsequently increased chains may be accommodated within this particular arrangement.

The entropy of the $\mathrm{N}$-Iso transition, measured for propoxy homologue is lower than that reported for BNC$72^{[34]}$ suggesting that the odd parity contributes to the greater effective molecular curvature and consequently reduces isotropization temperature. Combined experimental and computational studies showed that a bend angle in the region of $125^{\circ}$ is the optimum for a material to exhibit the twist-bend nematic phase. ${ }^{[38]}$ Thus, a small fluctuation in the bend angle of 6 a may disrupt the formation of the $\mathrm{N}_{\text {тв }}$ phase, which even in ethoxy homologues appears on cooling just $1{ }^{\circ} \mathrm{C}$ before crystallization. The reduction in clearing and melting temperatures but also supercooling effect are the most pronounced for the dimer with propargyloxy terminal chains. This may be attributed to the joined contribution of the increased effective molecular 


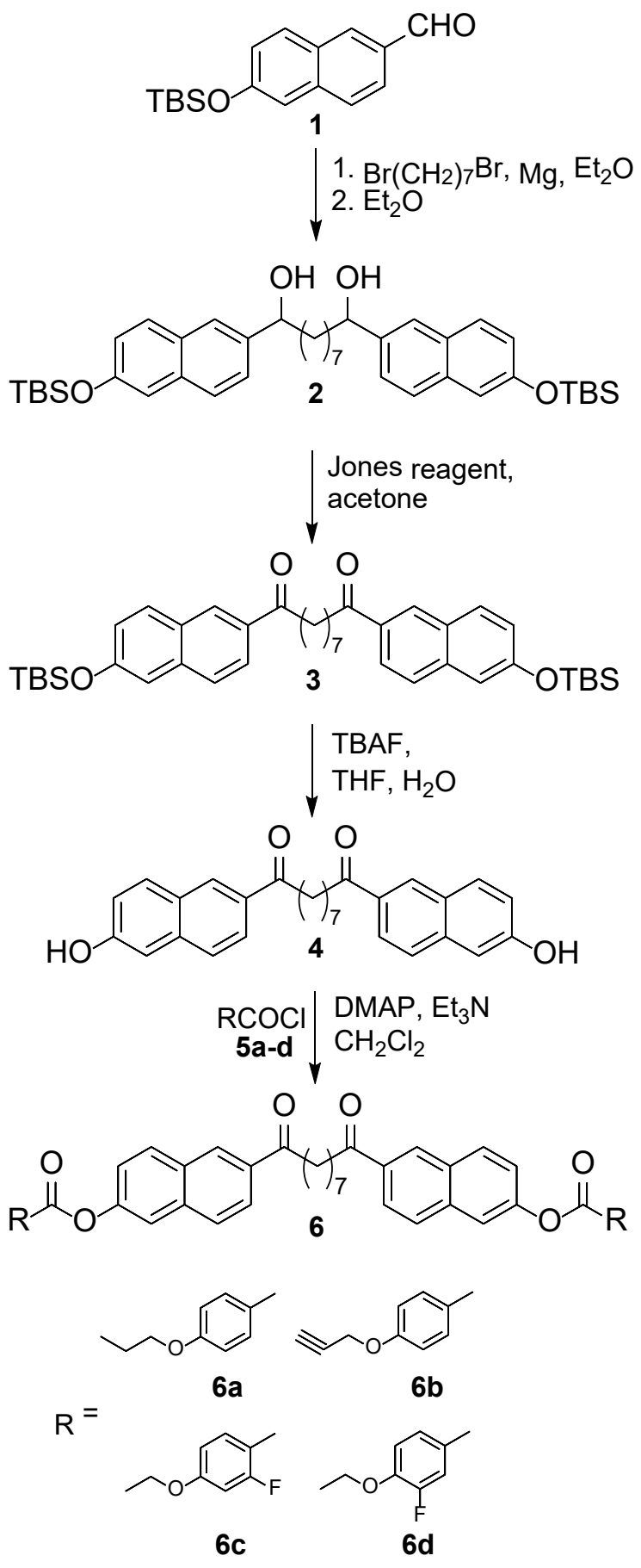

Scheme 1. Synthesis of naphthyl-based diketones $6 a-d$.

curvature and the incompatibility of propargyloxy terminal chains and the aliphatic spacer.

As expected, the inclusion of a lateral fluoro substituent reduces the $\mathrm{N}$-Iso transition temperatures. The magnitude of the reduction depends on the position of the lateral fluoro substituent in the outer-ring of the mesogenic core. Fluoro-substitution in the ortho position $(\mathbf{6 c})$
Table 1. Transition temperatures $\left({ }^{\circ} \mathrm{C}\right)$, enthalpies $\left(\mathrm{KJ} \mathrm{mol}^{-1}\right)$ in italics and the dimensionless value of $\Delta S / R$ in [] for dimers $6 a-d$.

\begin{tabular}{|c|c|c|c|c|c|}
\hline Dimer & $\mathrm{Cr}$ & & $\mathrm{N}$ & & Iso \\
\hline $6 a$ & $\bullet$ & $\begin{array}{c}165 \\
65.25[17.91]\end{array}$ & $\bullet$ & $\begin{array}{c}222 \\
1.82[0.44]\end{array}$ & • \\
\hline $6 b$ & • & $\begin{array}{c}146 \\
67.05[19,2]\end{array}$ & $\bullet$ & $\begin{array}{c}205 \\
1.91[0.48]\end{array}$ & $\bullet$ \\
\hline $6 c^{(a)}$ & • & $\begin{array}{c}155 \\
50.94[14.30]\end{array}$ & • & $\begin{array}{c}227 \\
2.42[0.58]\end{array}$ & • \\
\hline $6 d$ & $\bullet$ & $\begin{array}{c}170 \\
62.10[16.84]\end{array}$ & $\bullet$ & $\begin{array}{c}220 \\
1.49[0.36]\end{array}$ & • \\
\hline
\end{tabular}
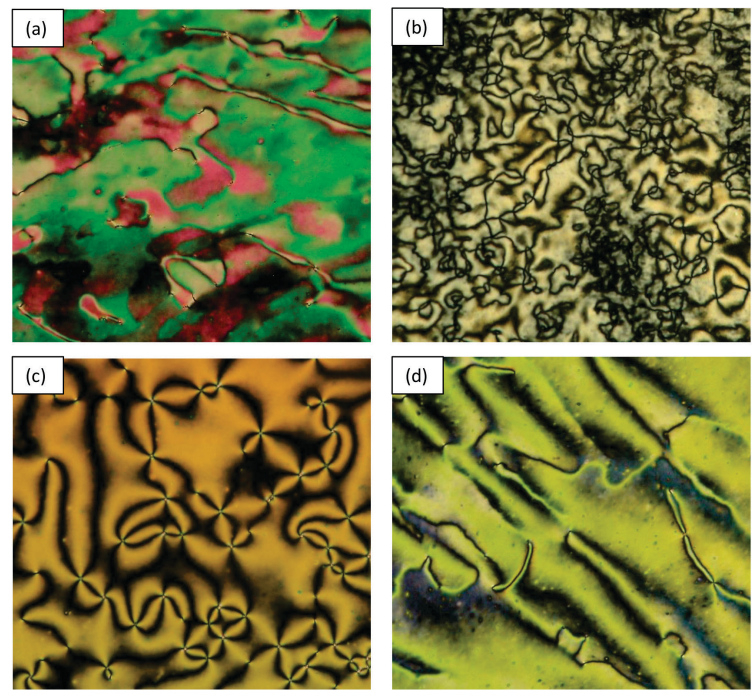

Figure 2. Schlieren and marbled textures characteristic for the nematic phase obtained on cooling at $186^{\circ} \mathrm{C}$ for (a) $6 a$, (b) $6 b,(c) 6 c$ and (d) $6 d$.

decreases both clearing and melting temperatures resulting in the wide range nematogen material. Fluorosubstitution in the meta position (6d), lowers the clearing point further but increases the melting temperature for 10 ${ }^{\circ} \mathrm{C}$. However, on cooling, it crystalizes at even lower temperature than parent BNC-72 and yet does not show the $\mathrm{N}_{\text {тв }}$ phase. Despite several studies on the laterally fluorinated bimesogens suggested that the position of fluoro-substituent is not critical for the formation of the $\mathrm{N}_{T B}$ phase, ${ }^{[38-40]}$ non-of the prepared dimers exhibit the $\mathrm{N}_{T B}$ phase. Since a fluoro-substituent is not very different in size as compared to the hydrogen it replaces, its effect on the overall shape is negligible. However, the high polarity of the fluoro-substituent and its position within the mesogenic core, cause the changes in conformational distribution. This affects the efficiency of molecular packing and 


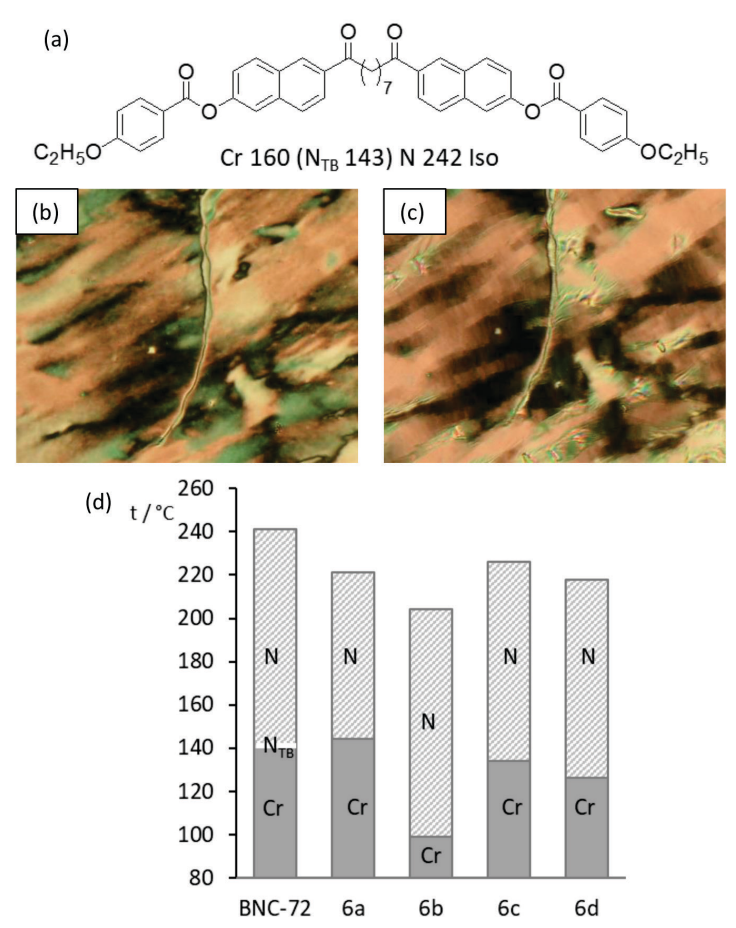

Figure 3. (a) Chemical structure and transition temperatures of BNC-72, ${ }^{[34]}$ (b) marbled texture of the nematic phase, (c) blocky texture characteristic for the N- $\mathrm{N}_{\text {тв }}$ phase transition, (d) plots of the difference in transition temperatures between newly prepared compounds 6a- $d$ and ethoxy analogue obtained on cooling.

consequently alter transition properties. These results show that the mesomorphic behaviour of bent-shaped dimers can be altered by a small change in molecular curvature, by the introduction of the incompatible parts, which obstruct microphase separation, and by the change in conformational distribution.

\section{CONCLUSION}

In the presented study we have reported the synthesis and mesomorphic properties of novel naphthyl-based diketones, having variant terminal chains and lateral fluorosubstitution positioned on the outer-ring of the mesogenic core. Investigation of mesomorphic properties showed that all newly prepared materials exhibit a broad temperature range of the nematic phase with no nematic to $\mathrm{N}_{\text {TB }}$ transition being observed. In general, structural modifications, either by changing the type of the terminal chain or by the introduction of lateral fluoro-atom, result in the reduction of the clearing temperatures while the melting temperatures are variable. Overall our study demonstrates how subtle changes in chemical structure can be used to tune the efficiency of molecular packing and consequently transition properties. In perspective, modification can be employed in tailoring specific electro-optical properties that might lead to possible technological applications.

\section{EXPERIMENTAL}

All the solvents were either puriss p.a. quality or distilled over appropriate drying reagents. All other reagents were purchased from commercial sources and used without purifications. For the chromatographic separations silica gel (Fluka Analytical, 35-75 $\mu \mathrm{m}$ ) was used. Analytical thinlayer cromatography was performed on silica gel plates (DC-Alufolien-Kieselgel $\mathrm{F}_{254}$, Sigma Aldrich). Visualization was carried out under ultra-violet irradiation (254 nm). NMR spectra were recorded on Bruker AV $600 \mathrm{MHz}$ and 300 $\mathrm{MHz}$ spectrometers, operating at 150.92 or $75.47 \mathrm{MHz}$ for ${ }^{13} \mathrm{C}$ and 600.13 or $300.13 \mathrm{MHz}$ for ${ }^{1} \mathrm{H}$ nuclei. The NMR spectra were taken in $\mathrm{CDCl}_{3}$ or DMSO-d6 at ambient temperature using TMS as a reference. Multiplets are abbreviated as follows: $\mathrm{br}$ - broad; $\mathrm{s}$ - singlet; $\mathrm{d}$-doublet; $\mathrm{t}$ - triplet; $\mathrm{q}$ - quartet; $\mathrm{m}$ - multiplet. $\mathrm{CHN}$ analysis were done on Perkin Elmer 2400 Series II CHNS analyser. Infrared spectra were recorded with a Bruker ABB Bomem FTIR spectrometer. Melting points were determined using an Electrothermal 9100 apparatus in open capillaries and are uncorrected. Textures were examined using an Olympus BX51 polarising microscope equipped with a Linkam TH600 hot stage and PR600 temperature controller and the Olympus C 5050 ZOOM digital camera. Phase transition temperatures and corresponding enthalpies were determined from thermograms recorded on Perkin-Elmer Diamond DSC, operated at scanning rates of $5{ }^{\circ} \mathrm{C} \mathrm{min}-1$. The compounds 1-4 were prepared following the procedures described earlier. ${ }^{[34]}$ The NMR spectra of new compounds are given in Supplementary Information.

\section{General Procedure for the Synthesis of 4-O-Substituted Benzoic Acids 5a-d}

To a solution of 4-hydroxybenzoic acid (1 equiv.) in absolute $\mathrm{MeOH}(40 \mathrm{~mL})$ concentrated sulfuric acid was added ( 0.1 equiv.). The reaction mixture was heated at reflux for $24 \mathrm{~h}$, and then cooled to $\mathrm{rt}$. The solvent was removed under reduced pressure. A saturated aqueous solution of $\mathrm{NaHCO}_{3}$ $(40 \mathrm{~mL})$ was added and the aqueous layer was extracted with diethyl eter $(3 \times 15 \mathrm{~mL})$. The organic extracts were dried over anhydrous $\mathrm{Na}_{2} \mathrm{SO}_{4}$, filtered, and the solvent was removed under reduced pressure. Crude ester was dissolved in acetone $(30 \mathrm{~mL})$ and potassium carbonate (1.5 equiv.) and 1-bromoethane (3 equiv.) were added. The reaction mixture was heated at reflux for $48 \mathrm{~h}$, and then cooled to rt. The solvent was removed under reduced pressure and water was added. The aqueous layer was extracted with $\mathrm{CH}_{2} \mathrm{Cl}_{2}(3 \times 15 \mathrm{~mL})$. The organic extracts were 
dried over anhydrous $\mathrm{Na}_{2} \mathrm{SO}_{4}$, filtered, and the solvent was removed under reduced pressure. The obtained crude product was then dissolved in $96 \% \mathrm{EtOH}(35 \mathrm{~mL})$ and aqueous solution of $\mathrm{NaOH}(15 \mathrm{~mL}, 40 \%)$ was added. The reaction mixture was heated at reflux overnight. Mixture was cooled, and $\mathrm{pH}$ was adjusted to 1 by addition of concentrated $\mathrm{HCl}$ to the reaction mixture. The precipitate was filtered, washed with water and dried to yield crude $\mathbf{5 a}-\mathbf{d}$. The compounds $\mathbf{5 a - d}$ were purified by crystallization from boiling $96 \% \mathrm{EtOH}$.

\section{4-PROPOXYBENZOIC ACID (5a)}

Prepared according to the general procedure from 4-hydroxybenzoic acid $(2.00 \mathrm{~g})$ and obtained as a white solid $(2.20 \mathrm{~g}$, $85 \%)$.

${ }^{1} \mathrm{H} \mathrm{NMR}\left(\mathrm{CDCl}_{3}, 600 \mathrm{MHz}\right) \delta / \mathrm{ppm}: 1.05(\mathrm{t}, J=7.4 \mathrm{~Hz}$, $3 \mathrm{H}), 1.81-1.87(\mathrm{~m}, 2 \mathrm{H}), 3.99(\mathrm{t}, J=6.6 \mathrm{~Hz}, 3 \mathrm{H}), 6.94(\mathrm{~d}, J=$ $8.9 \mathrm{~Hz}, 2 \mathrm{H}), 8.06(\mathrm{~d}, J=8.9 \mathrm{~Hz}, 2 \mathrm{H}) ;{ }^{13} \mathrm{C}\left(\mathrm{CDCl}_{3}, 151 \mathrm{MHz}\right)$ $\delta /$ ppm: 10.6, 22.6, 69.9, 114.3, 121.5, 132.5, 163.8, 172.3. $\mathrm{Mp} 144-145^{\circ} \mathrm{C}$.

\section{4-(PROP-2-YN-1-YLOXY)BENZOIC ACID (5b)}

Prepared according to the general procedure from 4-hydroxybenzoic acid $(2.00 \mathrm{~g})$ and obtained as a white solid $(2.13 \mathrm{~g}$, $82 \%)$.

${ }^{1} \mathrm{H}$ NMR (DMSO-d6, $300 \mathrm{MHz}$ ) $\delta / \mathrm{ppm}: 3.61(\mathrm{t}, J=2.4$ $\mathrm{Hz}, 1 \mathrm{H}), 4.88$ (d, $J=2.4 \mathrm{~Hz}, 2 \mathrm{H}), 7.07$ (d, $J=8.9 \mathrm{~Hz}, 3 \mathrm{H}), 7.90$ $(\mathrm{d}, J=9.0 \mathrm{~Hz}, 3 \mathrm{H}), 12.67$ (bs, $1 \mathrm{H}$ ); ${ }^{13} \mathrm{C}$ (DMSO-d6, $75 \mathrm{MHz}$ ) S/ppm: 55.6, 78.7, 78.8, 114.7, 123.7, 131.3, 160.7, 166.9. $\mathrm{Mp} 215-217^{\circ} \mathrm{C}$.

\section{4-ETOXY-2-FLUOROBENZOIC ACID (5c)}

Prepared according to the general procedure from 4-hydroxy2-fluorobenzoic acid (2.22 g) and obtained as a white solid (2.31 g, 88\%).

${ }^{1} \mathrm{H}$ NMR (DMSO-d6, $600 \mathrm{MHz}$ ) $\delta / \mathrm{ppm}: 1.32$ (t, $J=7.0$ $\mathrm{Hz}, 3 \mathrm{H}), 4.10(\mathrm{q}, \mathrm{J}=6.7 \mathrm{~Hz}, 2 \mathrm{H}), 6.80-6.87(\mathrm{~m} \mathrm{2H}), 7.80(\mathrm{t}, J$ $=8.7 \mathrm{~Hz}, 1 \mathrm{H}$ ), 12.83 (bs, $1 \mathrm{H}) ;{ }^{13} \mathrm{C}$ (DMSO-d6, $151 \mathrm{MHz}$ ) $\delta /$ ppm: 14.3, 64.1, $102.7\left({ }^{2} J_{C F}=25.8 \mathrm{~Hz}\right), 110.9\left({ }^{4} J_{C F}=2.9\right.$ $\mathrm{Hz}), 111.0,133.3\left({ }^{4} J_{C F}=2.9 \mathrm{~Hz}\right), 162.8\left({ }^{1} J_{C F}=257.4 \mathrm{~Hz}, \mathrm{C}-\mathrm{F}\right)$, $163.4\left({ }^{3} J_{C F}=11.5 \mathrm{~Hz}\right), 164.7\left({ }^{3} J_{C F}=3.7 \mathrm{~Hz}\right) . \mathrm{Mp} 187-189^{\circ} \mathrm{C}$.

\section{4-ETOXY-3-FLUOROBENZOIC ACID (5d)}

Prepared according to the general procedure from 4-hydroxy3-fluorobenzoic acid (2.20 g) and obtained as a white solid (1.50 g, $57 \%)$.

${ }^{1} \mathrm{H}$ NMR (DMSO-d6, $300 \mathrm{MHz}$ ) $\delta / \mathrm{ppm}: 1.36$ (t, $J=7.0$ $\mathrm{Hz}, 3 \mathrm{H}), 4.18(\mathrm{q}, J=7.0 \mathrm{~Hz}, 2 \mathrm{H}), 7.24(\mathrm{t}, J=8.6 \mathrm{~Hz}, 1 \mathrm{H}), 7.66$ (dd, $J=11.9,2.0 \mathrm{~Hz}, 1 \mathrm{H}$ ), 7.74 (ddd, $J=8.6,2.0,0.9 \mathrm{~Hz}, 1 \mathrm{H}$ ); ${ }^{13} \mathrm{C}$ (DMSO-d6, $75 \mathrm{MHz}$ ) $\delta / \mathrm{ppm}: 14.4,64.6,114.1,116.5$, $123.2\left({ }^{3} J_{C F}=6.0 \mathrm{~Hz}\right), 126.8\left({ }^{3} J_{C F}=3.2 \mathrm{~Hz}\right), 150.3\left({ }^{2} J_{C F}=10.4\right.$ $\mathrm{Hz}), 150.9\left({ }^{1} J_{C F}=244.6 \mathrm{~Hz}, \mathrm{C}-\mathrm{F}\right), 166.2\left({ }^{4} J_{C F}=2.5 \mathrm{~Hz}\right) . \mathrm{Mp}$ 193- $195^{\circ} \mathrm{C}$.

\section{General Procedure for the Synthesis of Naphthyl-based Diketones 6a-d}

4-O-substituted benzoic acid $\mathbf{5 a - d}$ (5 equiv.) was suspended in toluene. Oxalyl chloride ( 6.5 equiv.) and 1 drop of DMF were added and the reaction mixture was stirred for $1.5 \mathrm{~h}$ at room temperature. The solvent was removed under reduced pressure. The residue was dissolved in $\mathrm{CH}_{2} \mathrm{Cl}_{2}(4 \mathrm{~mL})$ and was added dropwise to a cooled mixture $\left(0{ }^{\circ} \mathrm{C}\right.$ ) of compound 4 (1 equiv.), $\mathrm{Et}_{3} \mathrm{~N}$ (10 equiv.) and DMAP ( 0.15 equiv.) in $\mathrm{CH}_{2} \mathrm{Cl}_{2}(10 \mathrm{~mL})$. After the addition was complete, the reaction mixture was stirred at room temperature for $24 \mathrm{~h}$. The solvent was removed under reduced pressure. The residue was purified by column chromatography on silica gel $\left(\mathrm{CH}_{2} \mathrm{Cl}_{2} / \mathrm{MeOH}=30 / 1\right)$. The compounds $6 \mathrm{a}-\mathbf{d}$ were crystallized from acetone $/ \mathrm{CH}_{2} \mathrm{Cl}_{2}$ (3/1) to give a white solid (69-77\%).

\section{1,9-BIS[6-(4-PROPOXYBENZOYLOXY)NAPHTHALEN-2-YL]- NONANE-1,9-DIONE (6a)}

According to the general procedure, the 4-propoxybenzoyl chloride was prepared from 4-propoxybenzoic acid $\mathbf{5 a}$ (0.25 $\mathrm{g}, 1.13 \mathrm{mmol})$, oxalyl chloride $(0.13 \mathrm{~mL}, 1.50 \mathrm{mmol})$ and catalytic amount of DMF in toluene $(4 \mathrm{~mL})$. In the reaction with the compound $4(0.10 \mathrm{~g}, 0.23 \mathrm{mmol})$ the product $6 \mathrm{a}$ $(0.14 \mathrm{~g}, 77 \%)$ was obtained as a white solid, phase transition temperatures $\left({ }^{\circ} \mathrm{C}\right): \mathrm{Cr} \bullet 166 \bullet \mathrm{N} \bullet 227 \bullet \mathrm{I}$.

${ }^{1} \mathrm{H} \mathrm{NMR}\left(\mathrm{CDCl}_{3}, 300 \mathrm{MHz}\right) \delta / \mathrm{ppm}: 1.07(\mathrm{t}, J=7.4 \mathrm{~Hz}$, $6 \mathrm{H}), 1.41-1.53(\mathrm{~m}, 6 \mathrm{H}), 1.75-1.92(\mathrm{~m}, 8 \mathrm{H}), 3.11(\mathrm{t}, J=7.4 \mathrm{~Hz}$, $4 \mathrm{H}), 4.02(\mathrm{t}, J=6.6 \mathrm{~Hz}, 4 \mathrm{H}), 7.00(\mathrm{~d}, J=8.9 \mathrm{~Hz}, 4 \mathrm{H}), 7.43(\mathrm{dd}$, $J=8.9,2.3 \mathrm{~Hz}, 2 \mathrm{H}), 7.72(\mathrm{~d}, J=2.3 \mathrm{~Hz}, 2 \mathrm{H}), 7.87(\mathrm{~d}, J=8.7$ $\mathrm{Hz}, 2 \mathrm{H}), 8.02(\mathrm{~d}, J=9.0 \mathrm{~Hz}, 2 \mathrm{H}), 8.06(\mathrm{dd}, J=8.7,1.8 \mathrm{~Hz}, 2 \mathrm{H})$, $8.18(\mathrm{~d}, J=9.0 \mathrm{~Hz}, 4 \mathrm{H}), 8.52(\mathrm{~s}, 2 \mathrm{H}) ;{ }^{13} \mathrm{C}\left(\mathrm{CDCl}_{3}, 75 \mathrm{MHz}\right)$ $\delta / p p m: 10.4,22.5,24.4,29.2,29.4,38.6,69.8,114.4,118.8$, $121.2,122.5,124.7,128.2,129.4,130.5,131.1,132.4$, 134.3, 136.2, 150.7, 163.7, 164.9, 200.3. IR (KBr) $\tilde{v}_{\max } / \mathrm{cm}^{-1}$ : 2936, 1726, 1680, 1609, 1512, 1474, 1248, 1168, 1071, 766. Anal. Calcd. mass fractions of elements, $w / \%$, for $\mathrm{C}_{49} \mathrm{H}_{48} \mathrm{O}_{8}$ $(\mathrm{Mr}=764.923)$ are: C 76.94, H 6.33, found: C 76.59, H 6.27.

\section{1,9-BIS[6-(4-PROP-2-YN-1-YLOXY)BENZOYLOXY)- NAPHTHALEN-2-YL]NONANE-1,9-DIONE (6b)}

According to the general procedure, the 4-(prop-2-yn-1yloxy)benzoyl chloride was prepared from 4-(prop-2-yn-1yloxy)benzoic acid $5 \mathbf{b}(0.21 \mathrm{~g}, 1.15 \mathrm{mmol})$, oxalyl chloride $(0.13 \mathrm{~mL}, 1.50 \mathrm{mmol})$ and catalytic amount of DMF in toluene $(4 \mathrm{~mL})$. In the reaction with the compound $4(0.10$ $\mathrm{g}, 0.23 \mathrm{mmol})$ the product $6 \mathrm{~b}(0.13 \mathrm{~g}, 77 \%)$ was obtained as a white solid, phase transition temperatures $\left({ }^{\circ} \mathrm{C}\right)$ : $\mathrm{Cr} \cdot 145 \bullet \mathrm{N} \cdot 211 \bullet \mathrm{I}$.

${ }^{1} \mathrm{H} \mathrm{NMR}\left(\mathrm{CDCl}_{3}, 300 \mathrm{MHz}\right) \delta / \mathrm{ppm}: 1.40-1.52(\mathrm{~m}, 6 \mathrm{H})$, 1.76-1.89 (m, 4H), $2.58(\mathrm{t}, J=2.4 \mathrm{~Hz}, 2 \mathrm{H}), 3.11(\mathrm{t}, J=7.4 \mathrm{~Hz}$, $4 \mathrm{H}), 4.80(\mathrm{~d}, J=2.4 \mathrm{~Hz}, 4 \mathrm{H}), 7.09(\mathrm{~d}, J=8.9 \mathrm{~Hz}, 4 \mathrm{H}), 7.42$ (dd, $J=8.9,2.3 \mathrm{~Hz}, 2 \mathrm{H}), 7.72(\mathrm{~d}, J=2.3 \mathrm{~Hz}, 2 \mathrm{H}), 7.87(\mathrm{~d}, J=8.7$ 
$\mathrm{Hz}, 2 \mathrm{H}), 8.02(\mathrm{~d}, J=8.9 \mathrm{~Hz}, 2 \mathrm{H}), 8.06(\mathrm{dd}, J=8.6,1.7 \mathrm{~Hz}, 2 \mathrm{H})$, $8.22(\mathrm{~d}, J=8.9 \mathrm{~Hz}, 4 \mathrm{H}), 8.49(\mathrm{~s}, 2 \mathrm{H}) ;{ }^{13} \mathrm{C} \mathrm{NMR}\left(\mathrm{CDCl}_{3}, 75\right.$ $\mathrm{MHz}$ ) $\delta /$ ppm: 24.5, 29.4, 29.5, 38.8, 56.1, 76.4, 114.9, $118.9,122.5,122.6,124.9,128.3,129.5,130.7,131.2$, $132.5,134.4,136.3,150.8,162.0,164.8,200.4$, CH-alkynyl not visible. IR $(\mathrm{KBr}) \tilde{v}_{\max } / \mathrm{cm}^{-1}: 3286,2936,2123,1726$, 1680, 1609, 1512, 1474, 1248, 1168, 1071, 766. Anal. Calcd. mass fractions of elements, $w / \%$, for $\mathrm{C}_{49} \mathrm{H}_{40} \mathrm{O}_{8}(\mathrm{Mr}=$ 756.859) are: C 77.76, H 5.33; found: C 76.77, H 5.40.

\section{1,9-BIS[6-(4-ETOXY-2-FLUOROBENZOYLOXY)NAPHTHALEN- 2-YL]NONANE-1,9-DIONE (6c)}

According to the general procedure, the 4-etoxy-2fluorobenzoyl chloride was prepared from 4-etoxy-2fluorobenzoyl acid $5 c(0.20 \mathrm{~g}, 1.15 \mathrm{mmol})$, oxalyl chloride $(0.13 \mathrm{~mL}, 1.50 \mathrm{mmol})$ and catalytic amount of DMF in toluene $(4 \mathrm{~mL})$. In the reaction with the compound 4 ( 0.10 $\mathrm{g}, 0.23 \mathrm{mmol})$ the product $6 \mathrm{c}(0.14 \mathrm{~g}, 77 \%)$ was obtained as a white solid, phase transition temperatures $\left({ }^{\circ} \mathrm{C}\right)$ : $\mathrm{Cr} \cdot 139 \bullet \mathrm{Cr} \cdot 157 \cdot \mathrm{N} \cdot 232 \bullet \mathrm{I}$.

${ }^{1} \mathrm{H}$ NMR $\left(\mathrm{CDCl}_{3}, 300 \mathrm{MHz}\right) \delta / \mathrm{ppm}: 1.41-1.55(\mathrm{~m}$, $12 \mathrm{H}), 1.76-1.92(\mathrm{~m}, 4 \mathrm{H}), 3.10(\mathrm{t}, J=7.4 \mathrm{~Hz}, 4 \mathrm{H}), 4.12(\mathrm{q}, J=$ $7.0 \mathrm{~Hz}, 4 \mathrm{H}), 6.70(\mathrm{dd}, J=12.7,2.4 \mathrm{~Hz}, 2 \mathrm{H}), 6.79$ (dd, $J=8.9$, $2.4 \mathrm{~Hz}, 2 \mathrm{H}), 7.43(\mathrm{dd}, J=8.9,2.3 \mathrm{~Hz}, 2 \mathrm{H}), 7.74(\mathrm{~d}, J=2.3 \mathrm{~Hz}$, $2 \mathrm{H}), 7.87(\mathrm{~d}, J=8.7 \mathrm{~Hz}, 2 \mathrm{H}), 8.01(\mathrm{~d}, J=9.0 \mathrm{~Hz}, 2 \mathrm{H}), 8.03$ $8.13(\mathrm{~m}, 4 \mathrm{H}), 8.51(\mathrm{~s}, 2 \mathrm{H}) ;{ }^{13} \mathrm{C} \mathrm{NMR}\left(\mathrm{CDCl}_{3}, 75 \mathrm{MHz}\right) \delta / \mathrm{ppm}$ : 14.7, 24.6, 29.4, 29.5, 38.8, 64.5, $103.1\left({ }^{2} J_{C F}=25.6 \mathrm{~Hz}\right)$, $109.8\left({ }^{2} J_{C F}=9.7 \mathrm{~Hz}\right), 111.1\left({ }^{3} J_{C F}=2.8 \mathrm{~Hz}\right), 118.9,122.5$, $124.8,128.3,129.5,130.7,131.2,134.0\left({ }^{4} J_{C F}=2.3 \mathrm{~Hz}\right)$, $134.5,136.3,150.5,162.5\left({ }^{2} J_{C F}=9.0 \mathrm{~Hz}\right), 164.2\left({ }^{1} J_{C F}=256.9\right.$ $\mathrm{Hz}, \mathrm{C}-\mathrm{F}), 164.9\left({ }^{3} J_{C F}=11.7 \mathrm{~Hz}\right), 200.4 . \mathrm{IR}(\mathrm{KBr}) \tilde{v}_{\max } / \mathrm{cm}^{-1}$ : 2936, 1726, 1680, 1609, 1512, 1474,1248, 1168, 1071, 766. Anal. Calcd. mass fractions of elements, $w / \%$, for $\mathrm{C}_{47} \mathrm{H}_{42} \mathrm{~F}_{2} \mathrm{O}_{8}(\mathrm{Mr}=772.853)$ are: $\mathrm{C} 73.04, \mathrm{H} 5.48$; found: $\mathrm{C}$ 72.93, H 5.69 .

\section{1,9-BIS[6-(4-ETOXY-3-FLUOROBENZOYLOXY)NAPHTHALEN- 2-YL]NONANE-1,9-DIONE (6d)}

According to the general procedure, the 4-etoxy-3fluorobenzoyl chloride was prepared from 4-etoxy-3fluorobenzoic acid $\mathbf{5 d}(0.20 \mathrm{~g}, 1.15 \mathrm{mmol})$, oxalyl chloride $(0.13 \mathrm{~mL}, 1.50 \mathrm{mmol})$ and catalytic amount of DMF in toluene $(4 \mathrm{~mL})$. In the reaction with the compound $4(0.10$ $\mathrm{g}, 0.23 \mathrm{mmol})$ the product $6 \mathrm{~d}(0.11 \mathrm{~g}, 69 \%)$ was obtained as a white solid, phase transition temperatures $\left({ }^{\circ} \mathrm{C}\right)$ : $\mathrm{Cr} \cdot 172 \cdot \mathrm{N} \cdot 224 \bullet$ I.

${ }^{1} \mathrm{H} \mathrm{NMR}\left(\mathrm{CDCl}_{3}, 600 \mathrm{MHz}\right) \delta / \mathrm{ppm}: 1.42-1.51(\mathrm{~m}, 6 \mathrm{H})$, $1.52(\mathrm{t}, J=7.0 \mathrm{~Hz}, 6 \mathrm{H}), 1.79-1.87(\mathrm{~m}, 4 \mathrm{H}), 3.10(\mathrm{t}, J=7.4 \mathrm{~Hz}$, $4 \mathrm{H}), 4.22(\mathrm{q}, J=7.0 \mathrm{~Hz}, 4 \mathrm{H}), 7.05(\mathrm{t}, J=8.3 \mathrm{~Hz}, 2 \mathrm{H}), 7.41(\mathrm{dd}$, $J=8.8,2.3 \mathrm{~Hz}, 2 \mathrm{H}), 7.72(\mathrm{~d}, J=2.3 \mathrm{~Hz}, 2 \mathrm{H}), 7.87(\mathrm{~d}, J=8.7$ $\mathrm{Hz}, 2 \mathrm{H}), 7.94$ (dd, $J=11.5,2.1 \mathrm{~Hz}, 2 \mathrm{H}), 7.98-8.03(\mathrm{~m}, 4 \mathrm{H})$, $8.06(\mathrm{dd}, J=8.6,1.7 \mathrm{~Hz}, 2 \mathrm{H}), 8.49(\mathrm{~s}, 2 \mathrm{H}) ;{ }^{13} \mathrm{C} \mathrm{NMR}\left(\mathrm{CDCl}_{3}\right.$,
$151 \mathrm{MHz}$ ) $\delta / \mathrm{ppm}: 14.7,24.6,29.4,29.5,38.8,65.2,113.59$ $\left({ }^{4} J_{C F}=1.9 \mathrm{~Hz}\right), 118.02\left({ }^{2} J_{C F}=20.1 \mathrm{~Hz}\right), 118.8,121.78\left({ }^{3} J_{\mathrm{CF}}=\right.$ $6.5 \mathrm{~Hz}), 122.3,124.9,127.64\left({ }^{3} J_{C F}=3.3 \mathrm{~Hz}\right), 128.3,129.5$, $130.7,131.3,134.5,136.3,150.6,152.0\left({ }^{1} J_{C F}=247.3 \mathrm{~Hz}, \mathrm{C}-\right.$ F), $152.1\left({ }^{2} J_{C F}=10.7 \mathrm{~Hz}\right), 164.1,200.3 . I R(K B r) \tilde{v}_{\max } / \mathrm{cm}^{-1}$ : 2936, 1726, 1680, 1609, 1512, 1474, 1248, 1168, 1071, 766. Anal. Calcd. mass fractions of elements, $w / \%$, for $\mathrm{C}_{47} \mathrm{H}_{42} \mathrm{~F}_{2} \mathrm{O}_{8}(\mathrm{Mr}=772.853)$ are: $\mathrm{C} 73.04, \mathrm{H} 5.48$; found: $\mathrm{C}$ 73.08, H 5.87 .

Acknowledgment. The authors thank the Croatian Science Foundation (grant ref. IP-2014-09-1525) for financial support.

Supplementary Information. Supporting information to the paper is attached to the electronic version of the article at: https://doi.org/10.5562/cca3541.

PDF files with attached documents are best viewed with Adobe Acrobat Reader which is free and can be downloaded from Adobe's web site.

\section{REFERENCES}

[1] J. W. Goodby, I. M. Saez, S. J. Cowling, V. Görtz, M. Draper, A. W. Hall, S. Sia, G. Cosquer, S.-E. Lee, E. P. Raynes, Angew. Chem. Int. Ed. 2008, 47, 2754-2787. https://doi.org/10.1002/anie.200701111

[2] T. Kato, N. Mizoshita, K. Kishimoto, Angew. Chem. Int. Ed. 2006, 45, 38-68.

https://doi.org/10.1002/anie.200501384

[3] H. K. Bisoyi, S. Kumar, Chem. Soc. Rev. 2010, 40, 306319. https://doi.org/10.1039/B901793N

[4] C. T. Imrie, P. A. Henderson, Chem. Soc. Rev. 2007, 36, 2096. https://doi.org/10.1039/b714102e

[5] M. Šepelj, A. Lesac, U. Baumeister, S. Diele, H. L. Nguyen, D. W. Bruce, J Mater Chem 2007, 17, 11541165. https://doi.org/10.1039/B612517D

[6] M. Cestari, S. Diez-Berart, D. A. Dunmur, A. Ferrarini, M. R. de La Fuente, D. J. B. Jackson, D. O. Lopez, G. R. Luckhurst, M. A. Perez-Jubindo, R. M. Richardson, et al., Phys. Rev. E 2011, 84, 031704.

https://doi.org/10.1103/PhysRevE.84.031704

[7] V. Borshch, Y.-K. Kim, J. Xiang, M. Gao, A. Jákli, V. P. Panov, J. K. Vij, C. T. Imrie, M. G. Tamba, G. H. Mehl, et al., Nat. Commun. 2013, 4, 2635.

https://doi.org/10.1038/ncomms3635

[8] W. D. Stevenson, Z. Ahmed, X. B. Zeng, C. Welch, G. Ungar, G. H. Mehl, Phys. Chem. Chem. Phys. 2017, 19, 13449-13454.

https://doi.org/10.1039/C7CP01404J

[9] M. Cestari, E. Frezza, A. Ferrarini, G. R. Luckhurst, J. Mater. Chem. 2011, 21, 12303.

https://doi.org/10.1039/c1jm12233a 
[10] D. Chen, M. Nakata, R. Shao, M. R. Tuchband, M. Shuai, U. Baumeister, W. Weissflog, D. M. Walba, M A. Glaser, J. E. Maclennan, et al., Phys. Rev. E 2014, $89,022506$.

https://doi.org/10.1103/PhysRevE.89.022506

[11] I. Dozov, Europhys. Lett. EPL 2001, 56, 247-253. https://doi.org/10.1209/epl/i2001-00513-x

[12] D. Chen, J. H. Porada, J. B. Hooper, A. Klittnick, Y. Shen, M. R. Tuchband, E. Korblova, D. Bedrov, D. M. Walba, M. A. Glaser, et al., Proc. Natl. Acad. Sci. 2013, 110, 15931-15936. https://doi.org/10.1073/pnas.1314654110

[13] C. Zhu, M. R. Tuchband, A. Young, M. Shuai, A. Scarbrough, D. M. Walba, J. E. Maclennan, C. Wang, A. Hexemer, N. A. Clark, Phys. Rev. Lett. 2016, 116, 147803. https://doi.org/10.1103/PhysRevLett.116.147803

[14] A. Ferrarini, Liq. Cryst. 2017, 44, 45-57. https://doi.org/10.1007/s35144-017-0048-8

[15] L. Beguin, J. W. Emsley, M. Lelli, A. Lesage, G. R. Luckhurst, B. A. Timimi, H. Zimmermann, J. Phys. Chem. B 2012, 116, 7940-7951. https://doi.org/10.1021/jp302705n

[16] C. Meyer, I. Dozov, Soft Matter 2016, 12, 574-580. https://doi.org/10.1039/C5SM02018B

[17] V. P. Panov, J. K. Vij, G. H. Mehl, Liq. Cryst. 2017, 44, 147-159.

https://doi.org/10.1080/02678292.2016.1254289

[18] R. J. Mandle, J. W. Goodby, RSC Adv 2016, 6, 3488534893. https://doi.org/10.1039/C6RA03594A

[19] S. M. Jansze, A. Martínez-Felipe, J. M. D. Storey, A. T. M. Marcelis, C. T. Imrie, Angew. Chem. Int. Ed. 2015, 54, 643-646. https://doi.org/10.1002/anie.201409738

[20] W. D. Stevenson, J. An, X. Zeng, M. Xue, H. Zou, Y. Liu, G. Ungar, Soft Matter 2018, 14, 3003-3011. https://doi.org/10.1039/C7SM02525D

[21] H. Sasaki, Y. Takanishi, J. Yamamoto, A. Yoshizawa, Soft Matter 2016, 12, 3331-3339. https://doi.org/10.1039/C5SM02969D

[22] R. J. Mandle, J. W. Goodby, Angew. Chem. Int. Ed. 2018, 57, 7096-7100. https://doi.org/10.1002/anie.201802881

[23] S. P. Sreenilayam, V. P. Panov, J. K. Vij, G. Shanker, Liq. Cryst. 2017, 44, 244-253. https://doi.org/10.1080/02678292.2016.1253878

[24] R. J. Mandle, Soft Matter 2016, 12, 7883-7901. https://doi.org/10.1039/C6SM01772J

[25] J. P. Abberley, S. M. Jansze, R. Walker, D. A. Paterson, P. A. Henderson, A. T. M. Marcelis, J. M. D. Storey, C. T. Imrie, Liq. Cryst. 2017, 44, 68-83. https://doi.org/10.1080/02678292.2016.1275303
[26] R. J. Mandle, E. J. Davis, C. T. Archbold, C. C. Voll, J. L. Andrews, S. J. Cowling, J. W. Goodby, Chem. Eur. J. 2015, 21, 8158-8167.

https://doi.org/10.1002/chem.201500423

[27] T. Ivšić, U. Baumeister, I. Dokli, A. Mikleušević, A. Lesac, Liq. Cryst. 2017, 44, 93-105. https://doi.org/10.1080/02678292.2016.1225832

[28] C. T. Archbold, J. L. Andrews, R. J. Mandle, S. J. Cowling, J. W. Goodby, Liq. Cryst. 2017, 44, 84-92. https://doi.org/10.1080/02678292.2016.1240247

[29] A. Lesac, U. Baumeister, I. Dokli, Z. Hameršak, T. Ivšić, D. Kontrec, M. Viskić, A. Knežević, R. J. Mandle, Liq. Cryst. 2018, 45, 1101-1110.

https://doi.org/10.1080/02678292.2018.1453556

[30] R. J. Mandle, J. W. Goodby, Chem. - Eur. J. 2016, 22, 18456-18464.

https://doi.org/10.1002/chem.201604030

[31] E. E. Pocock, R. J. Mandle, J. W. Goodby, Soft Matter 2018, 14, 2508-2514.

https://doi.org/10.1039/C7SM02364B

[32] D. A. Paterson, J. P. Abberley, W. T. Harrison, J. Storey, C. T. Imrie, Liq. Cryst. 2017, 44, 127-146. https://doi.org/10.1080/02678292.2016.1274293

[33] N. Sebastián, B. Robles-Hernández, S. Diez-Berart, J. Salud, G. R. Luckhurst, D. A. Dunmur, D. O. López, M. R. de la Fuente, Liq. Cryst. 2017, 44, 177-190. https://doi.org/10.1080/02678292.2016.1218963

[34] A. Knežević, M. Sapunar, A. Buljan, I. Dokli, Z. Hameršak, D. Kontrec, A. Lesac, Soft Matter 2018, 14, 8466-8474.

https://doi.org/10.1039/C8SM01569D

[35] J. W. Goodby, R. J. Mandle, E. J. Davis, T. Zhong, S. J. Cowling, Liq. Cryst. 2015, 42, 593-622. https://doi.org/10.1080/02678292.2015.1030348

[36] C. Meyer, I. N. Dozov, I. Dokli, A. Knezevic, A. Lesac, P. Davidson, G. R. Luckhurst, in (Eds.: I. Muševič, L.-C. Chien, D.J. Broer, V.G. Chigrinov), SPIE, 2018, p. 35.

[37] M. Hird, Chem. Soc. Rev. 2007, 36, 2070. https://doi.org/10.1039/b610738a

[38] R. J. Mandle, C. T. Archbold, J. P. Sarju, J. L. Andrews, J. W. Goodby, Sci. Rep. 2016, 6, 36682. https://doi.org/10.1038/srep36682

[39] Z. Ahmed, C. Welch, G. H. Mehl, RSC Adv. 2015, 5, 93513-93521. https://doi.org/10.1039/C5RA18118F

[40] R. J. Mandle, E. J. Davis, C.-C. Voll, C. T. Archbold, J. W. Goodby, S. J. Cowling, Liq. Cryst. 2015, 42, 688-703. https://doi.org/10.1080/02678292.2014.974698 